impulses, as even the most rascally demagogue knows. Learning, philosophy and art are realities to which men will devote their lives, creating rather than copying, with no ulterior or mercenary aim. The arts and virtues bring a new and incalculable feature into the story of evolution. Some, at least, of their achievements outlive kingdoms and empires, seeming immortal.

Men are, for the most part, enthusiastic admirers of virtue, even to the extent of devising laws to ensure its maintenance. Very many of them are actual exponents of virtue in their personal relations; but in public affairs and in the mass they are often content to behave as animals rather than as men. "Manners makyth man" is perhaps the most concise specific diagnosis ever published. But there is only one law of evolution, common to individuals and races alike. If mankind as a whole neglects its "manners", it abandons any claim it may have to qualitative difference from other animals. There is no doubt of man's ability to become the most successful type of animal that has ever existed; but the reward of success in that direction is death.

The love of truth, greatest of all virtues, is especially an attribute of men of science. In this we are idealists, for the truth is unattainable, however worth the seeking. We know that all the progress that our species has made, in material as well as in mental affairs, is the result of the search for truth. We find ourselves strangers in a world riddled with more or less blatant deceit; but we still follow our ideal, confident that all other paths are blind. We recognize in the conception of truth something eternal, not subject to the laws of change and decay.

We know that idealism is the goal and incentive in all actions that can truly be described as human. To the idealist, environment is something to be overcome or adapted into service; the story of human progress is one of triumph over circumstances. The self-styled 'realist', who advocates acceptance of, and submission to, his temporary environment, is less than a man; he follows in the tradition of the beasts that perish.

To idealists palæontology has no message, save to welcome them as something new in Nature. To realists, who seek material success in the struggle for existence, palæontology, with millions of years of history as its authority, declares emphatically, "You have been warned."

\title{
Obituary
}

\section{Mr. C. Fitzhugh Talman}

$\mathrm{W}^{1}$ ITH the death on July 24, at the age of sixty-one years, of Mr. C. F. Talman, the U.S. Weather Bureau loses one of its best known members.

Talman was born at Detroit on August 31, 1874, and joined the Weather Bureau in October 1896. From 1898 until 1899 he was in charge of the meteorological stations maintained by the United States in South America and the West Indies; afterwards he was attached to the Weather Bureau Library, where he found his true vocation. He received the official title of librarian in 1908, and though he became junior professor in 1912, professor in 1914 and meteorologist in 1922, he remained in charge of the library throughout. He was intensely interested in bibliographical work, and his knowledge of meteorological literature became almost unique. In addition to the annotated lists of new books and papers which he compiled regularly for the Monthly Weather Review, he delved deeply into the history of meteoro. logical terminology, publishing his results in semipopular articles on "The Language of Meteorology", "The Meteorological Isograms" and "The Vocabulary of Weather". The last, which was reprinted in the Quarterly Journal of the Royal Meteorological Society for 1925, ends with the words: "I have been gathering wind-names from the literature of all countries, ancient and modern, for many years, and endeavour- ing to elucidate them from both the etymological and scientific standpoints. ... It is a fascinating occupation and $I$ only regret that I have, apparently, the whole field to myself".

Another outcome of Talman's hobby was his selection as meteorological adviser for the "Standard Dictionary" in 1910-11. He had a pleasant literary style, which also found expression in two popular books "Meteorology, the Science of the Atmosphere" (reprinted in 1925 as "Our Weather") and "The Realm of the Air" (1931) and in numerous newspaper articles, but his interest was the collector's rather than the author's, and he published only a small part of his material. It is greatly to be hoped that means will be found for editing and publishing his notes.

We regret to announce the following deaths:

Dr. J. B. E. A. Chareot, the well-known French explorer of the Antarctic, on September 16, aged sixty-nine years.

Mr. J. W. Gordon, K.C., honorary secretary of the Optical Convention in 1912, and author of "Generalized Linear Perspective, with Special Reference to Photographic Land Surveying", on September 21, aged eighty-two years.

Mr. Ernest Payne, a pioneer in X-ray research work, on September 20, aged seventy-six years. 